\title{
Utilization of salt marsh plants by postlarval brown shrimp: carbon assimilation rates and food preferences
}

\author{
Daniel F. Gleason* \\ Department of Biology, University of Houston, Houston, Texas 77004, USA
}

\begin{abstract}
Changes in stable carbon isotope ratios were monitored at $4 \mathrm{~d}$ intervals for postlarval Penaeus aztecus Ives reared on plant foods representative of those found within a Spartina alterniflora Loisel salt marsh. Plant materials fed to shrimp, individually and in combination, included Skeletonema costatum (Greville) Cleve, Isochrysis sp., Spartina detritus, and epiphytes that grow on Spartina. Results of carbon isotope analyses indicated that the most rapid changes in tissue $\delta^{13} \mathrm{C}$ values occurred when shrimp were fed $S$. costatum alone or all foods combined. In both of these treatments the half-life of tissue carbon was reached before the first doubling of weight. Although shrimp fed epiphytes showed growth, significant assimilation of diet carbon was not detected. Food preferences were assessed with those materials which promoted growth (i.e. S. costatum and epiphytes) and, although there was no preference for $S$. costatum and epiphytes together compared to epiphytes alone, selection for both of these materials was greater than for $S$. costatum alone. Results indicate that (i) certain plants common in Spartina salt marshes, such as the diatom $S$. costatum, can be important for metabolic maintenance in postlarval $P$. aztecus and (ii) postlarval brown shrimp may have substrate preferences that are not related to plant food value.
\end{abstract}

\section{INTRODUCTION}

Penaeus aztecus Ives (brown shrimp) uses Spartina alterniflora Loisel salt marshes during postlarval and juvenile stages (Williams 1959, Gunter 1961, Weinstein 1979). This mobile macroconsumer is a conspicuous member of the marsh community from early spring to late summer with highest densities in areas dominated by vegetation (Zimmerman et al. 1984). Although field studies indicate that $P$. aztecus consumes many types of plant materials including plant detritus and benthic algae (Jones 1973), a large proportion (up to $50 \%$ ) of gut contents is unidentifiable (Jones 1973, George 1978, Chong \& Sasekumar 1981). Recent laboratory experiments, however, suggest that even though growth rates of postlarval $P$. aztecus reared on plant diets do not approach those obtained for shrimp fed animal tissue, certain plants common in salt marshes, such as planktonic and epiphytic

\footnotetext{
- Present address: University of Houston, Marine Science
} Program, 4700 Avenue U, Galveston, Texas 77550, USA diatoms, may provide a maintenance diet during periods when preferred foods are not encountered (Gleason \& Zimmerman 1984). The ability to temporarily survive on diets consisting solely of plant material may be useful because potential animal prey, such as harpacticoid copepods and epibenthic polychaetes, can vary both spatially and temporally (Reice \& Stiven 1983, Wiltse et al. 1984).

Animals assimilate diet carbon without significantly altering the carbon isotopic composition (DeNiro \& Epstein 1978, Haines \& Montague 1979). This results in an eventual equilibrium in ${ }^{13} \mathrm{C} /{ }^{12} \mathrm{C}$ ratios between animal tissues and diet. Using stable carbon isotopes, Fry \& Arnold (1982) established metabolic turnover rates for postlarval Penaeus aztecus reared on animal diets. In contrast, the present investigation determines carbon turnover rates for postlarval $P$. aztecus fed various salt marsh plants (i.e. detrital, epiphytic, and planktonic). I predicted that plants providing a suitable maintenance diet, in terms of tissue carbon replacement, should have turnover rates similar to those found by Fry \& Arnold (1982). In addition, since penaeid 
shrimp may exhibit food preferences (Jones 1973. Moriarty 1976, George 1978, Chong \& Sasekumar 1981), relations between this variable and carbon assimilation rates were tested.

\section{METHODS AND MATERIALS}

\section{Assimilation experiments}

Collection and culture of shrimp. Penaeus aztecus postlarvae were captured in the surf off Galveston Island, Texas, USA, with a hand-towed beam trawl (Renfro 1963) and starved for no less than 12 but no more than $24 \mathrm{~h}$ prior to initiation of experiments. To avoid cannibalism, shrimp were reared individually in $250 \mathrm{ml}$ beakers filled with $5 \mu \mathrm{m}$ filtered sea water. Salinity and temperature were maintained at $25 \pm 1 \%$ and $25 \pm 1{ }^{\circ} \mathrm{C}$ while the photoperiod was kept constant at $12 \mathrm{~h}$ light/12 $\mathrm{h}$ dark (see Gleason \& Zimmerman 1984). Four types of representative food materials were used: Skeletonema costatum (Greville) Cleve (a planktonic diatom), Isochrysis sp. (a flagellated green alga), Spartina alterniflora detritus (decaying vascular plant tissue mixed with the blue-green alga Aphanothece stagnina [Spreng] A. Br.) and Spartina epiphytes (consisting of many species of blue-green algae, green algae, and diatoms). S. costatum and Isochrysis were obtained from algal cultures virtually free of contamination and were presented to the shrimp in densities of approximately $5 \times 10^{5}$ cells $\mathrm{ml}^{-1}$. Detritus and epiphyte samples were collected from a Spartina marsh on the West Bay side of Galveston Island, Texas, USA, and cleaned of fauna according to Gleason \& Zimmerman (1984). The algal complex comprising the epiphyte assemblage was found to be dominated by Ulothrix flacca (Dillw.) Thur, U. subflaccida Wille, Oscillatoria curviceps Ag. ex Gamont, and Nitzschia clausterium (Ehr.) Wm. Smith. In treatments containing detritus or epiphytes, a $0.5 \mathrm{ml}$ aliquot of plant material was placed in each $250 \mathrm{ml}$ beaker. Assimilation was assessed in 6 treatments (24 replicates per treatment): 4 containing a single food source, 1 with a mixture of all foods, and 1 with no food. At $4 \mathrm{~d}$ intervals up to and including $16 \mathrm{~d}, 6$ specimens were removed and weighed on a microbalance to the nearest $0.2 \mathrm{mg}$. The initial shrimp weights were not significantly different between treatments (1-way ANOVA; $F=0.8$, d.f. $=$ 5,186, P $\gg 0.05$ ).

Since variances between treatments were heteroscedastic ( $F$-max test, $P>0.05$ ) and in some instances shrimp lost weight, growth data were transformed by $\log _{10}(x+3)$ prior to 1 -way analysis of variance. Backtransformed values are presented to facilitate interpretation.
Preparation of tissue samples: shrimp. The time necessary for the ${ }^{13} \mathrm{C} /{ }^{12} \mathrm{C}$ ratio in the shrimp tissues to equilibrate with the ratio found in its diet can be determined by periodically sampling the shrimp tissues for $\delta^{13} \mathrm{C}$ values (Fry \& Arnold 1982). Therefore, an initial sample (Day 0 ) of 10 shrimp, along with 4 of the 6 individuals removed at $4 \mathrm{~d}$ intervals in each treatment, were sacrificed for stable carbon isotope analysis. Individual postlarvae were placed in beakers containing sea water until their intestinal tracts were empty (normally 3 to $4 \mathrm{~h}$ ), thus avoiding any potential contaminants of nonassimilable carbon that may have been ingested. Shrimp were killed by freezing and stored at $-10^{\circ} \mathrm{C}$. Later, shrimp were thawed, treated for $5 \mathrm{~min}$ with $5 \%$ phosphoric acid to remove any carbonates (Haines \& Montague 1979, Fry \& Arnold 1982), and dried at $60^{\circ} \mathrm{C}$ for a minimum of $48 \mathrm{~h}$. Dried specimens were weighed to the nearest $0.2 \mathrm{mg}$ and stored in a desiccator prior to combustion.

Preparation of tissue samples: plant materials. Plant samples were collected initially and at $4 \mathrm{~d}$ intervals from treatments without shrimp and analyzed for $\delta^{13} \mathrm{C}$ values. Spartina detritus and Spartina epiphyte samples were washed free of contaminating meiofauna by the same procedure indicated in the growth experiments, while Skeletonema costatum and Isochrysis sp. samples were filtered onto $1.2 \mu \mathrm{m} \mathrm{GF/C} \mathrm{grade} \mathrm{What-}$ man glass fiber filters. These filters had been precombusted at $500^{\circ} \mathrm{C}$ for $2 \mathrm{~h}$. All plant samples were dried at $60^{\circ} \mathrm{C}$ for a minimum of $48 \mathrm{~h}$ and stored in a desiccator prior to combustion.

Carbon isotope analysis. Entire shrimp, ranging in dry weight from 0.6 to $3.2 \mathrm{mg}$, and 3 to $5 \mathrm{mg}$ (dry weight) aliquots of plant material were added individually to $15.2 \mathrm{~cm}$ lengths of $9 \mathrm{~mm}$ O.D. quartz tubing containing 90 to $100 \mathrm{mg} \mathrm{CuO}$ and $20 \mathrm{mg}$ silver wool. Tubes enclosing tissue samples were evacuated to $<10^{-2}$ mbar, sealed, then combusted at $850^{\circ} \mathrm{C}$ for $1 \mathrm{~h}$ (Boutton et al. 1983). After cooling to room temperature the gas was released into a vacuum line. Water was removed by condensation in an ethanol-dry ice trap, oxides of nitrogen and sulfur were reduced by passage through copper powder heated to $230^{\circ} \mathrm{C}, \mathrm{CO}_{2}$ was collected with liquid nitrogen, and any gases not condensed with liquid nitrogen were pumped away.

Purified $\mathrm{CO}_{2}$ samples were analyzed with a Micromass $602 \mathrm{C}$ mass spectrometer and expressed as $\delta^{13} \mathrm{C}$ values based on the PDB standard according to the convention of Craig (1953) where:

$\delta^{13} \mathrm{C}$ in $\%=\left[\frac{{ }^{13} \mathrm{C} /{ }^{12} \mathrm{C} \text { sample }-{ }^{13} \mathrm{C} /{ }^{12} \mathrm{C} \text { standard }}{{ }^{13} \mathrm{C} /{ }^{12} \mathrm{C} \text { standard }}\right] \times 1000$

Preliminary analyses indicated that the ratio of ${ }^{13} \mathrm{C} /$ ${ }^{12} \mathrm{C}$ was relatively homogeneous in ground tissue from 
the salt marsh plant Spartina alterniflora. Therefore, this material was used as a working standard to quantify variability in $\delta^{13} \mathrm{C}$ values due to machine error and combustion procedures. S. alterniflora samples analyzed on each day that the mass spectrometer was used had a standard deviation of $\pm 0.10 \%$ (mean $\delta^{13} \mathrm{C}=$ -12.34 , range $=0.26, \mathrm{n}=19$ ). Replicate analyses of individual plant samples within experimental treatments also were taken to check for carbon isotope ratio variability. These were found to have a standard deviation of $\pm 0.10 \%$ (absolute mean difference $=0.10 \%$, range $=0.4, \mathrm{n}=11$ ). Procedural variabilities due to machine error, combustion, and plant tissue heterogeneity resulted in a total standard deviation of only $\pm 0.20 \%$.

Boutton et al. (1983) indicated that the variability in isotope values can be reduced by combusting samples at $850^{\circ} \mathrm{C}$ as opposed to $550^{\circ} \mathrm{C}$. Therefore, I attribute the high degree of precision obtained here to the increased combustion temperature. Other studies have indicated similar isotope precision when combusting samples at 800 to $900^{\circ} \mathrm{C}$ (Stephenson \& Lyon 1982).

\section{Preference experiments}

Feeding preferences were assessed only with those materials which had been previously found to promote growth (i.e. Skeletonema costatum and Spartina epiphytes) (Gleason \& Zimmerman 1984). Postlarval Penaeus aztecus were captured in the surf, brought into the laboratory, and acclimated for $4 \mathrm{~d}$ in beakers containing a combination of $S$. costatum and epiphytes. Conditions of culture were the same as those described in the growth experiments.

Food preference experiments were conducted in $90 \times 15 \mathrm{~mm}$ Petri dishes. Skeletonema costatum and epiphytic plant materials were suspended in sea water and then filtered onto $35 \mathrm{~mm}$ diameter $1.2 \mu \mathrm{m}$ Whatman GF/C grade glass fiber filters. Each dish contained 3 equally spaced pads (epiphytes alone, S. costatum alone, epiphytes and $S$. costatum together). A $2.5 \mathrm{~cm}$ length of $15 \mathrm{~mm}$ PVC pipe, placed in the center of each vessel, served as a holding cylinder. Postlarvae were starved for 24 to $36 \mathrm{~h}$ prior to initiation of the experiments, and added to the cylinders in groups of 7 to increase sample sizes for statistical analysis. Preference experiments using 1 individual per replicate were found to have the same distributional patterns as those using 7 individuals per replicate (Table $6 ; \chi^{2}=$ 0.16 , d.f. $=3, \mathrm{P}>0.90$ ). Therefore, 7 specimens were considered appropriate for maximizing sample size while minimizing any possible group effects on preference.

After approximately $5 \mathrm{~min}$ in the holding cylinder shrimp were released by raising the pipe. Preference was measured by recording the number of individuals on each filter pad after $10 \mathrm{~min}$ and every 5 min thereafter for a total of 30 min (5 observations per replicate). Preliminary experiments showed that all shrimp guts were full after $30 \mathrm{~min}$. Preferences were monitored in 10 experiments during the day and 10 at night, for a total of 140 shrimp. Salinity and temperature were maintained at constant levels of $25 \pm 1 \%$ and $25 \pm 1{ }^{\circ} \mathrm{C}$ during all observations. Daylight experiments were conducted between 1400 and $1900 \mathrm{~h}$ under Sylvania $40 \mathrm{~W}$ daylight bulbs. Nighttime observations were made between 2100 and $0200 \mathrm{~h}$ with the aid of a $60 \mathrm{~W}$ Sylvania red bulb.

\section{RESULTS}

\section{Assimilation experiments}

Growth patterns for shrimp (Table 1) were similar to those found by Gleason \& Zimmerman (1984). Changes in weight (final weight - initial weight) were significantly different among treatments in those individuals surviving to $16 \mathrm{~d}$ (1-way ANOVA, $F=87.28$, d.f. $=$ $3,40, P<0.001)$. Increases in weight were greatest in the Skeletonema and Combination treatments followed by Spartina epiphytes (Table 1). In contrast, slight but nonsignificant decreases in body weight were observed for shrimp fed Spartina detritus. Although mortality reached $100 \%$ by Day 16 in both the Isochrysis and No Food treatments, significant increases in weight were not recorded during the $12 \mathrm{~d}$ that shrimp survived.

The $\delta^{13} \mathrm{C}$ values of the plant materials, measured at $4 \mathrm{~d}$ intervals, did not vary significantly within treatments (1-way ANOVA, $F=3.01$, d.f. $=4,10, \mathrm{P}>0.05$ for Isochrysis; $\mathrm{F}=2.56$, d.f. $=4,19, \mathrm{P}>0.05$ for

Table 1. Penaeus aztecus. Growth of postlarvae after $16 \mathrm{~d}$ reared on plant diets. No individuals in the Isochrysis or No Food treatments survived the full term. Values represent means with 1 standard error of the mean in parentheses. Groups with the same letter were not significantly different in change in weight (Duncan's multiple range test). The Combination treatment included all food types. Mean initial weight $=7.4 \mathrm{mg} \pm 0.42 \mathrm{SE}, \mathrm{n}=192$

\begin{tabular}{|lcccc|}
\hline Treatment & $\begin{array}{c}\text { Number } \\
\text { of indi- } \\
\text { viduals }\end{array}$ & $\begin{array}{c}\text { Change } \\
\text { in weight } \\
(\mathrm{mg})\end{array}$ & $\begin{array}{c}\text { Growth } \\
\text { rate } \\
\mathrm{mg} \mathrm{d}^{-1}\end{array}$ & $\begin{array}{c}\text { Signifi- } \\
\text { cance } \\
(\alpha=0.05)\end{array}$ \\
\hline Combination & 10 & $6.0(0.8)$ & $0.4(0.05)$ & $\mathrm{A}$ \\
Skeletonema & 11 & $4.4(0.3)$ & $0.3(0.02)$ & $\mathrm{A}$ \\
Epiphytes & 11 & $1.2(0.2)$ & $0.1(0.02)$ & $\mathrm{B}$ \\
Detritus & 12 & $-0.7(0.2)$ & 0.0 & $\mathrm{C}$ \\
\hline
\end{tabular}


detritus; $F=0.80$, d.f. $=4,19, P>0.10$ for epiphytes; $\mathrm{F}=0.79$, d.f. $=2,12, \mathrm{P}>0.10$ for Skeletonema). Isochrysis $\mathrm{sp}$. was the most depleted in ${ }^{13} \mathrm{C}$ while Spartina detritus was the most enriched (Table 2). Both S. costatum and Spartina epiphytes had values between Isochrysis and detritus, and could not be distinguished from each other on the basis of carbon isotopic values alone (Table 2).

Significant changes in animal tissue $\delta^{13} \mathrm{C}$ values occurred only in beakers containing Skeletonema costatum (Mann-Whitney U-test, $\mathrm{P} \ll 0.01$ ) or all plant materials ( $\mathrm{P} \ll 0.01$ ) (Fig. 1). Changes in all other treat-

Table $2 .{ }^{13} \mathrm{C}$ values for plant materials fed to shrimp. Plant samples were taken initially and every $4 \mathrm{~d}$ during the course of the experiment. Values were not significantly different within plant treatments over the $16 \mathrm{~d}$ (1-way ANOVA, $P>0.05$ for all materials). Values represent means of independent samples with 1 standard error of the mean in parentheses. Groups with the same letter were not significantly different (Duncan's multiple range test)

\begin{tabular}{|lccc|}
\hline \multicolumn{1}{|c}{ Plant material } & $\mathrm{N}$ & $\begin{array}{c}\delta^{13} \mathrm{C} \text { Value } \\
(\%)\end{array}$ & $\begin{array}{c}\text { Signifi- } \\
\text { cance } \\
(\alpha=0.05)\end{array}$ \\
\hline Spartina detritus & 24 & $-15.0(0.1)$ & $\mathrm{A}$ \\
Spartina epiphytes & 24 & $-18.3(0.2)$ & $\mathrm{B}$ \\
Skeletonema costatum & 17 & $-18.3(0.2)$ & $\mathrm{B}$ \\
Isochrysis sp. & 15 & $-20.0(0.2)$ & $\mathrm{C}$ \\
\hline
\end{tabular}

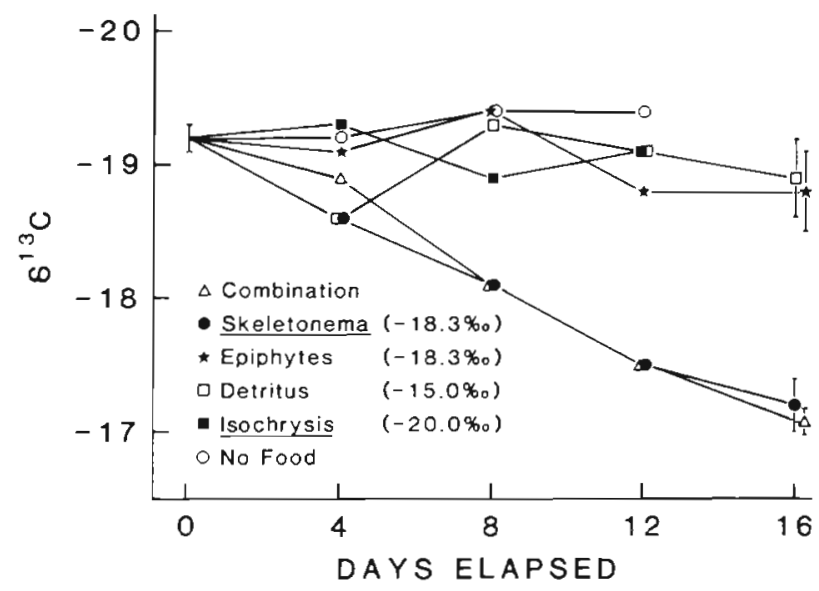

Fig. 1. Penaeus aztecus. Changes in $\delta^{13} \mathrm{C}$ as a function of time for postlarvae fed plant diets. All data points, except the initial sample $(n=10)$, represent means of 4 shrimp. Vertical bars around the initial and $16 \mathrm{~d}$ values represent 1 standard error of the mean (SE). The maximum SE found at all other sampling periods were $0.6,0.4$, and 0.2 for 4,8 , and $12 \mathrm{~d}$, respectively. Statistical analyses tested for differences between initial and final $\delta^{13} \mathrm{C}$ values within each treatment (Mann-Whitney U-test). Significant changes occurred only in those shrimp fed Skeletonema costatum alone $(\mathrm{P} \ll 0.01)$ or a combination of all foods $(\mathrm{P} \ll 0.01$ ). Within all other treatments the final values were not different from the initial value $(\mathrm{P}>0.05)$ ments were nonsignificant ( $\mathrm{P}>0.05$ in all cases, MannWhitney U-test). Postlarvae fed $S$. costatum alone became approximately $1 \%$ enriched relative to their food source (Table 3). All other individuals reared on single plant sources, except those on Isochrysis sp., remained depleted in ${ }^{13} \mathrm{C}$ relative to the respective plant material during the entire experiment (Table 3).

Assimilation could not be evaluated in Isochrysis treatments. Shrimp reared on Isochrysis $\mathrm{sp}$. were approximately $1 \%$ enriched relative to this algae initially, and throughout the $12 \mathrm{~d}$ that specimens survived. Since growth and survival on Isochrysis followed closely that obtained in No Food treatments, assimilation was assumed to be negligible.

Comparisons of the $\delta^{13} \mathrm{C}$ values at each of the 4 sampling days, between shrimp in Skeletonema and Mixed treatments, showed no significant differences (1-way ANOVA, P $\gg 0.05$ in all cases). Assimilation of diet carbon, displayed as change in $\delta^{13} \mathrm{C}$ as a function of wet weight (Fig. 2), followed a power function of the form $\delta=\mathrm{a}+\mathrm{bw}^{\mathrm{c}}$, where $\mathrm{c}=$ the metabolic constant, $\delta=$ the $\delta^{13} \mathrm{C}$ value, and $\mathrm{w}=$ the percent increase in the initial wet weight (Fry \& Arnold 1982). Since the rate of incorporation of ${ }^{13} \mathrm{C}$ into the tissues is affected by both growth and metabolic turnover (Fry \& Amold 1982), the curves displayed in Fig. 2 represent assimilation resulting from the combination of these proces-

Table 3. Comparisons between mean Penaeus aztecus $\delta^{13} \mathrm{C}$ values and the appropriate plant value, for postlarvae reared on individual plant food sources for $16 \mathrm{~d}$. The difference between the initial shrimp $\delta^{13} \mathrm{C}$ value and each plant value is represented as Day 0 in each treatment

\begin{tabular}{|c|c|c|}
\hline Treatment & Day & $\begin{array}{l}\delta^{13} \mathrm{C} \text { animal } \\
-\delta^{13} \mathrm{C} \text { food }\end{array}$ \\
\hline $\begin{array}{l}\text { Skeletonema } \\
(-18.3 \%)\end{array}$ & $\begin{array}{r}0 \\
4 \\
8 \\
12 \\
16\end{array}$ & $\begin{array}{l}-0.9 \\
-0.3 \\
+0.2 \\
+0.8 \\
+1.1\end{array}$ \\
\hline $\begin{array}{l}\text { Epiphytes } \\
(-18.3 \%)\end{array}$ & $\begin{array}{r}0 \\
4 \\
8 \\
12 \\
16\end{array}$ & $\begin{array}{l}-0.9 \\
-0.8 \\
-1.1 \\
-0.5 \\
-0.5\end{array}$ \\
\hline $\begin{array}{l}\text { Detritus } \\
(-15.0 \%)\end{array}$ & $\begin{array}{r}0 \\
4 \\
8 \\
12 \\
16\end{array}$ & $\begin{array}{l}-4.2 \\
-3.6 \\
-4.3 \\
-4.1 \\
-3.9\end{array}$ \\
\hline $\begin{array}{l}\text { Isochrysis } \\
(-20.0 \%)\end{array}$ & $\begin{array}{r}0 \\
4 \\
8 \\
12 \\
16\end{array}$ & $\begin{array}{l}+0.8 \\
+0.7 \\
+1.1 \\
+0.9 \\
-\end{array}$ \\
\hline
\end{tabular}




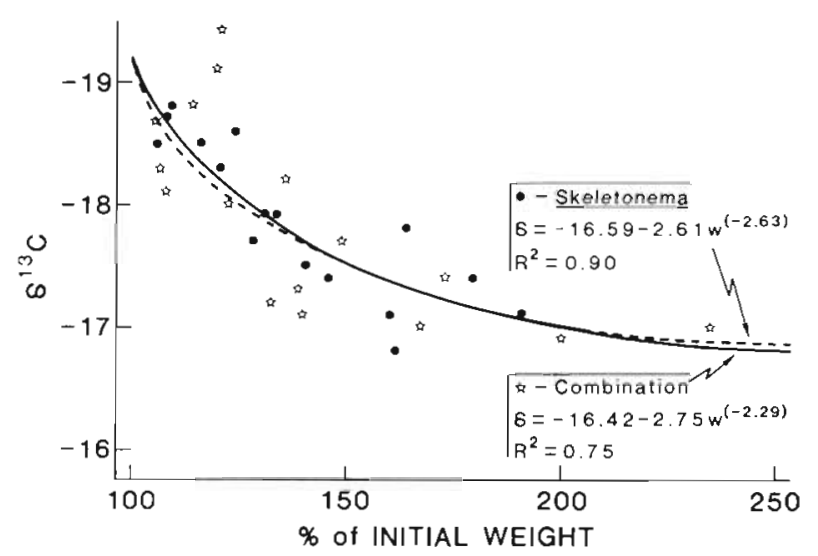

Fig. 2. Penaeus aztecus. Changes in $\delta^{13} \mathrm{C}$ as a function of weight for postlarvae fed plant diets. Power curves of the form $\delta=\mathrm{a}+\mathrm{bw}^{\mathrm{c}}$, where $\mathrm{c}=$ metabolic constant, were fitted to the data (see text for details). Curves represent the combined effects of growth and metabolic turnover on the incorporation of ${ }^{13} \mathrm{C}$ into the tissues. The more negative the value of $\mathrm{c}$ the more rapid the carbon turnover in the tissues. Metabolic constants were not significantly different (t-test, $P>0.05$ )

ses. Values for $\mathrm{a}, \mathrm{b}$, and $\mathrm{c}$ were determined according to the procedures of Fry \& Arnold (1982). Briefly, c was calculated by linear regression (Sokal \& Rohlf 1969), using transformed variables $(w, \delta)$ to $\left(w^{c}, \delta\right)$. The initial regression was conducted at $\mathrm{c}$ equal to -1 and was followed by subsequent regressions at decreasing increments of 0.01 units for $c$ until the least residual sum of squares was found. At this point a and b were also at their best-fit values. Power functions resulted in nearly identical $\delta^{13} \mathrm{C}$ assimilation curves for shrimp reared in Skeletonema and Combination treatments (Fig. 2). The metabolic constants (Table 4) were less

Table 4. Penaeus aztecus. Metabolic constants and half-lives of initial carbon when reared on plant and animal diets. The more negative the constant, the more rapid the rate of metabolic turnover. Initial weight $=100 \% ;$ C.L. $=$ confidence limit

(a) Plant diets on which assimilation occurred. Metabolic constants were not significantly different (t-test, $\mathrm{P}>0.05$ )

\begin{tabular}{lccc}
\hline Treatment & $\begin{array}{c}\text { Metabolic } \\
\text { constant (c) }\end{array}$ & $\begin{array}{c}95 \% \mathrm{CL} \\
\text { for c }\end{array}$ & $\begin{array}{c}\text { \% Initial } \\
\text { weight at } \\
\text { half-life } \\
\text { of carbon }\end{array}$ \\
\hline Combination & -2.29 & $-1.55,-3.27$ & 171 \\
Skeletonema & -2.63 & $-2.11,-3.28$ & 153 \\
\hline
\end{tabular}

(b) Animal diets

\begin{tabular}{llll}
\hline Shrimp & -2.18 & $-1.92,-2.46$ & 180 \\
Squid & -2.27 & $-1.26,-4.37$ & 172 \\
Brine shrimp & -1.45 & $-0.94,-2.94$ & 467 \\
- Data from Fry \& Arnold (1982) &
\end{tabular}

than -1 , confirming that ${ }^{13} \mathrm{C}$ was assimilated via growth and turnover processes ( $\mathrm{c}=-1$ would indicate no turnover; Fry \& Arnold 1982). Confidence limits (95\%) for c were calculated according to Silvert (1979; in Fry \& Arnold 1982). Comparing the $c$ values through the use of a t-test showed that the metabolic constants were not significantly different at the 0.05 level (Table 4). The weight at which half of the initial tissue carbon was replaced by the new carbon was calculated by setting $\mathrm{T}(\mathrm{w})=0.05$ in the equation $\mathrm{T}(\mathrm{w})=\mathrm{w}^{\mathrm{c}+1}$, where $\mathrm{T}(\mathrm{w})=$ turnover function, $\mathrm{w}=$ percent increase in wet weight, and $\mathrm{c}=$ metabolic constant (Fry \& Arnold 1982). In both treatments, the half-life of carbon was reached in the shrimp tissues before the first doubling of weight (Table 4). Metabolic constants for shrimp fed animal versus plant diets were not significantly different indicating equivalent turnover rates (Table 4). In fact, in all cases, except for squid diets, turnover of structural carbon was more rapid for shrimp reared on plants.

\section{Preference experiments}

Shrimp were observed to follow the same behavioral patterns regardless of the time of day. Since no feeding occurred during the first $5 \mathrm{~min}$ following release from the PVC holding chamber, this initial period was not included in statistical analyses.

Preferences for food or substrate did not differ significantly in time between the 5 min intervals in either the day or night trials (Table $5 ; \chi^{2}=16.67$, d.f. $=12$,

Table 5. Penaeus aztecus. Distribution on each food source at 5 observation penods. Values at each time interval represent the sum of 10 independent replicates ( 7 shrimp replicate ${ }^{-1}$ ). Preferences did not vary with time over the $30 \mathrm{~min}$ period during day or night trials (G-test for goodness-of-fit; $P>0.10$ for day, $P>0.50$ for night)

\begin{tabular}{|c|c|c|c|c|}
\hline \multirow{2}{*}{$\begin{array}{l}\text { Time } \\
\text { elapsed } \\
\text { (min) }\end{array}$} & \multicolumn{4}{|c|}{ Treatments } \\
\hline & $\begin{array}{l}\text { Epiphytes } \\
\text { alone }\end{array}$ & $\begin{array}{c}\text { Skeleto } \\
\text { nema }+ \\
\text { epiphytes }\end{array}$ & $\begin{array}{c}\text { Skeleto } \\
\text { nema } \\
\text { alone }\end{array}$ & $\begin{array}{c}\text { Off food } \\
\text { substrates }\end{array}$ \\
\hline \multicolumn{5}{|c|}{ Day trials } \\
\hline 10 & 23 & 25 & 12 & 10 \\
\hline 15 & 24 & 25 & 10 & 11 \\
\hline 20 & 27 & 26 & 7 & 10 \\
\hline 25 & 29 & 20 & 4 & 17 \\
\hline 30 & 28 & 23 & 2 & 17 \\
\hline \multicolumn{5}{|c|}{ Night trials } \\
\hline 10 & 26 & 21 & 10 & 13 \\
\hline 15 & 31 & 28 & 5 & 6 \\
\hline 20 & 26 & 28 & 6 & 10 \\
\hline 25 & 32 & 24 & 4 & 10 \\
\hline 30 & 32 & 25 & 3 & 10 \\
\hline
\end{tabular}


$P>0.10$ for day; $\chi^{2}=10.28$, d.f. $=12, P>0.50$ for night). Furthermore, pooling the values over $30 \mathrm{~min}$ (Table 6) resulted in no significant differences in distributional patterns between day and night trials $\left(\chi^{2}=\right.$ 4.16 , d.f. $=3, P>0.10$ ). The total number of individuals observed at the various food stations, however, were found to deviate significantly from what would be expected by random placement (Table $6 ; \chi^{2}=$ 195.78, d.f. $=3, P<0.01$ ). Although preferences for pads containing Skeletonema costatum and epiphytes together or epiphytes alone were not different $\left(\chi^{2}=\right.$ 1.96, d.f. $=1, P>0.20$ ), selection for both of these treatments was greater than for $S$. costatum alone $\left(\chi^{2}=\right.$ 164.66 , d.f. $=2, P<0.01$ ). The combined results indicate that postlarvae are not selecting for plant substrates strictly on the basis of their ability to be assimilated.

\section{DISCUSSION}

This study demonstrates that postlarval Penaeus aztecus can readily assimilate certain common salt marsh plant materials. Specifically, carbon turnover in the tissues of shrimp fed Skeletonema costatum alone or a mixture of all foods is not significantly different from that found for postlarvae reared on several types of animal diets. The ability of $P$. aztecus to assimilate $S$. costatum supports the hypothesis that diatoms may represent an important food source for developing shrimp (Gleason \& Zimmerman 1984). In contrast, Spartina detritus and one species of planktonic green algae, Isochrysis sp., provide no direct benefit in terms of metabolic maintenance. Feeding preferences, however, do not correspond with either growth or changes in tissue $\delta^{13} \mathrm{C}$ (i.e. epiphytes are preferred over $S$. costatum), indicating that the postlarvae may have a primary preference for substrate that is not directly coupled with plant food value. Perhaps the darker color and more 3-dimensional surface associated with
Spartina epiphytes is more attractive as a refuge from predators.

Fry \& Arnold (1982) showed that changes in tissue $\delta^{13} \mathrm{C}$ values for postlarval brown shrimp fed animal diets are more a function of increases in weight (i.e. addition of new carbon) than carbon turnover from metabolic maintenance (i.e. replacement of existing structural carbon with new carbon). The results of my study agree because changes in carbon isotope ratios occurred where increases in shrimp body weight were greatest (i.e. Skeletonema costatum alone and all foods in combination). However, even though the growth rates for shrimp fed $S$. costatum, or a combination of all foods, were generally lower than in this previous study, the metabolic constants and half-lives of carbon were similar. This comparison indicates that certain marsh plants, such as $S$. costatum can be as important as animal constituents for metabolic maintenance. In fact, recent field experiments show that a diet consisting of both animal and plant sources is needed to obtain maximum growth rates (Gleason \& Wellington unpubl.).

It has been suggested that the resolution of turnover rates increases as the difference between the diet and the initial consumer $\delta^{13} \mathrm{C}$ value becomes greater (Fry \& Arnold 1982). Specifically, an isotopic change of $>2$ to $3 \%$ is considered the minimum needed for field populations. The present data indicate that this large a difference may not be necessary for assimilation studies conducted under highly controlled conditions in the laboratory. For example, although the difference in $\delta^{13} \mathrm{C}$ values between Skeletonema costatum and the shrimp at Day 0 was only $1 \%$, the degree of resolution was quite high $\left(\mathrm{r}^{2}=0.90\right.$, Fig. 2). Undoubtedly, resolution was enhanced by the ${ }^{13} \mathrm{C}$ enrichment that occurred in the shrimp tissues. This process resulted in a total change after assimilation of approximately $2 \%$ (Table 3). The process resulting in fractionation of $+1 \%$ is not completely understood but is thought to be the result of respiratory $\mathrm{CO}_{2}$ being more depleted in ${ }^{13} \mathrm{C}$ than the

Table 6. Pendeus aztecus. Distribution on each food source during day and night observations. Values represent 10 independent replicates observed 5 times. The 5 observations were summed resulting in 1 data point per replicate for each treatment. Distributional patterns did not vary significantly between day versus night or between 7 individuals replicate ${ }^{-1}$ versus 1 individual replicate ${ }^{1}$ (G-test for goodness of fit, $P>0.10$ and $P>0.99$ respectively). Preference for epiphytes alone and Skeletonema and epiphytes together was significantly greater than for Skeletonema alone (G-test for goodness of fit. $\mathrm{P}<0.01$ )

\begin{tabular}{|c|c|c|c|c|c|c|}
\hline \multirow[t]{2}{*}{ Time } & \multirow{2}{*}{$\begin{array}{l}\text { Number of } \\
\text { replicates }\end{array}$} & \multirow[t]{2}{*}{ N replicate ${ }^{-1}$} & \multicolumn{4}{|c|}{ Treatments } \\
\hline & & & $\begin{array}{l}\text { Epiphytes } \\
\text { alone }\end{array}$ & $\begin{array}{l}\text { Skeletonema } \\
\text { + epiphytes }\end{array}$ & $\begin{array}{c}\text { Skeletonema } \\
\text { alone }\end{array}$ & $\begin{array}{l}\text { Off food } \\
\text { substrates }\end{array}$ \\
\hline Day & 10 & 7 & 131 & 119 & 35 & 65 \\
\hline Night & 10 & 7 & 147 & 126 & 28 & 49 \\
\hline Overall & 20 & 7 & 139 & 123 & 32 & 57 \\
\hline Day & 7 & 1 & 14 & 12 & 3 & 6 \\
\hline
\end{tabular}


diet (DeNiro \& Epstein 1978). Although Fry \& Arnold (1982) did not observe this trend on all animal diets, the presence of plankton, which normally has a carbon value much more negative than some of the animal diets they provided (Haines \& Montague 1979), may have obscured this fractionation and also reduced resolution.

Shrimp reared on Spartina epiphytes showed growth even though no significant carbon turnover was detected. Several factors could account for this result. First, although the design of the preference experiments indicated that epiphytes were consumed, food preferences occurring on a microscale were not detectable. Since Spartina epiphytes represented a mixture of many species of diatoms, blue-green algae, and green algae, it is possible that the $\delta^{13} \mathrm{C}$ values resulted from the shrimp preferentially feeding on single species or combinations that were more depleted in ${ }^{13} \mathrm{C}$ (i.e. more negative $\delta^{13} \mathrm{C}$ value) relative to the entire algal complex. Another possible explanation is that all components of the epiphyte assemblage were consumed by Penaeus aztecus, but only sources with a net $\delta^{13} \mathrm{C}$ value more negative than the overall epiphyte value were assimilated. To avoid this potential problem attempts to evaluate feeding patterns of mobile macroconsumers in salt marshes must define precisely available food resources.

The lack of evidence for preferential feeding on Skeletonema costatum makes it difficult to understand why assimilation curves were nearly identical for shrimp fed $S$. costatum alone or all foods in combination. It is possible that in the combinations treatment postlarvae consumed an assortment of foods that resulted in $\delta^{13} \mathrm{C}$ values resembling $S$. costatum alone. This is unlikely, however, because previous experiments indicated no additive or synergistic effects on growth for shrimp reared on all possible combinations of these plants (Gleason \& Zimmerman 1984). Instead, I propose that postlarval brown shrimp possess an assimilation threshold, a point at which further consumption of a usable food source results in its passage through the gut as waste. This concept of 'superfluous feeding' has been exhibited by the cladoceran Daphnia longispina, and copepod Eudiaptomus sp., maintained on food concentrations greater than those found in nature (reviewed by Monakov 1972). Since S. costatum densities far exceeded those normally present in the salt marsh (S. R. Indelicato pers. comm.), shrimp preferentially settling and foraging on epiphytes in combination treatments may have also consumed $S$. costatum. A threshold assimilation would predict that $S$. costatum was consumed at a level sufficient to meet the maximum assimilation efficiency for this food source. Although 'superfluous feeding' may provide no selective advantage (Conover 1966), this behavior combined with an assimilation threshold might be expected to evolve if quality food patches are sparse and highly unpredictable. Future experiments should investigate the relation between shrimp feeding behavior and the distribution of food sources in the salt marsh.

Acknowledgements. I thank T W. Boutton, G. N. Cameron, R. B. Dunbar, L. E. Franklin, R. F. Maddocks, G. M. Wellington, R. J. Zimmerman, and several anonymous reviewers for their comments and criticisms on earlier drafts. Discussions with C. Brunet and S. Craig were also helpful. Additional gratitude goes to G. M. Wellington for his continual support and encouragement. I am indebted to R. B. Dunbar, S. Minnis, and $A$. Leventer for providing many hours of training and assistance in the techniques of stable carbon isotope analysis. Debbie Gleason deserves special thanks.

Carbon isotope analyses were performed at the Rice University Stable Isotope Facility, Houston, Texas. Financial support was provided by the University of Houston Coastal Center and the Texas A \& M University Sea Grant College Program. This work was part of a thesis submitted in partial fulfillment of the requirements for a M.S. degree in the Dept. of Biology, Univ. of Houston, Houston, Texas.

\section{LITERATURE CITED}

Boutton, T. W., Wong, W. W., Hachey, D. L., Lee, L. S., Cabrera, M. P., Klein, P. D. (1983). Comparison of quartz and pyrex tubes for combustion of organic samples for stable carbon isotope analysis. Analyt. Chem. 55: 1832-1833

Conover, R. J. (1966). Factors affecting the assimilation of organic matter by zooplankton and the question of superfluous feeding. Limnol. Oceanogr. 11: 346-354

Chong, V. C., Sasekumar. A. (1981). Food and feeding habits of the white prawn Penaeus merguiensis. Mar. Ecol. Prog. Ser. 5: 185-191

Craig, H. (1953). The geochemistry of the stable carbon isotopes. Geochim. cosmochim. Acta 3: 53-92

DeNiro, M. J., Epstein, S. (1978). Influence of diet on the distribution of carbon isotopes in animals. Geochim. cosmochim. Acta 42: 495-506

Fry, B., Arnold, C. (1982). Rapid C-13/C-12 turnover during growth of brown shrimp (Penaeus aztecus). Oecologia (Berl.) 54: 200-204

George, M. J. (1978). The food of the shrimp Metapenaeus monoceros (Fabricus) caught from the backwaters. Indian J. Fish. 21: 495-500

Gleason, D. F., Zimmerman, R. J. (1984). Herbivory potential of postlarval brown shrimp associated with salt marshes. J. exp. mar. Biol. Ecol. 84: 235-246

Gunter, G. (1961). Habitat of juvenile shrimp (Family Penaeidae). Ecology 42: 598-600

Haines, E. B., Montague, C. L. (1979). Food sources of estuarine invertebrates analyzed using ${ }^{13} \mathrm{C} /{ }^{12} \mathrm{C}$ ratios. Ecology 60: 48-56

Jones, R. R. (1973). Utilization of Louisiana estuarine sediments as a source of nutrition for the brown shrimp Penaeus aztecus Ives. Ph.D. dissertation, Louisiana State University, Baton Rouge

Monakov, A. V. (1972). Review of studies on feeding of aquatic invertebrates conducted at the Institute of Biology of Inland Waters, Academy of Science, USSR. J. Fish. Res. Bd Can. 29: 363-383 
Moriarty, D. J. W. (1976). Quantitative studies on bacteria and algae in the food of the mullet Mugil cephalus L. and the prawn Metapenaeus bennettae (Racek and Dall) J exp. mar. Biol. Ecol. 22: 131-143

Reice, S. R., Stiven, A. E. (1983). Environmental patchiness, litter decomposition and associated faunal patterns in a Spartina alterniflora marsh. Estuar. coast. Shelf Sci. 16: $559-571$

Renfro, W. C. (1963). Small beam net for sampling postlarval shrimp. U.S. Fish. Wildl. Circ. 161: 86-87

Silvert, W. (1979). Practical curve fitting. Limnol. Oceanogr. 24: 767-773

Sokal, R. R., Rohlf, F. J. (1969). Biometry. W. H. Freeman and Co., San Francisco

Stephenson, R. L., Lyon, G. L. (1982). Carbon-13 depletion in an estuarine bivalve: detection of marine and terrestrial food sources. Oecologia (Berl.) 55: 110-113

Weinstein M. P. (1979). Shallow marsh habitats as primary nurseries for fishes and shellfish, Cape Fear River, North Carolina. Fish. Bull. U.S. 77: 339-358

Williams, A. B. (1959). Spotted and brown shrimp postlarvae (Penaeus) in North Carolina. Bull. mar. Sci. Gulf. Caribb. 9: $281-290$

Wiltse, W. I., Foreman, K. H., Teal, J. M., Valiela, I. (1984) Effects of predators and food resources on the macrobenthos of salt marsh creeks. J. mar. Res. 42: 923-942

Zimmerman, R. J., Minello, T., Zamora, G. (1984). Selection by Penaeus aztecus for vegetated habitat in a Galveston Bay salt marsh. Fish. Bull. U.S. 84: 325-336

This article was presented by Dr. G. W. Thayer; it was accepted for printing on April 24, 1986 